\title{
Lutero, um discípulo de Santo Agostinho?
}

\author{
[ LUTHER, AN AUGUNSTIN FOLLOWER? ]
}

\author{
Renan Pires Maia* \\ Faculdade Santíssima Trindade, Brasil
}

RESUMO: O presente trabalho se propõe a fazer uma análise da extensão da influência de Santo Agostinho sobre Lutero, no intuito de em algum sentido demarcar até que ponto Lutero permanece fiel a Santo Agostinho na defesa de suas visões doutrinárias. Sabe-se que Lutero era, no período anterior à Reforma, monge agostiniano, e durante e após a Reforma se utiliza de Santo Agostinho para defender suas visões doutrinárias: como, por exemplo, a doutrina da justificação somente pela Fé (Sola Fide) e salvação somente pela graça (Sola Gratia). De fato, Santo Agostinho se torna muito importante para os reformadores, sendo citado várias vezes nos escritos destes. Tais doutrinas centrais da Reforma em torno da Fé e da Graça são também amplamente defendidas nos escritos agostinianos. Porém, assim como podemos traçar paralelos entre as visões doutrinárias agostinianas e as visões luteranas, podemos, igualmente, perceber distanciamentos. Santo Agostinho, por exemplo, não defende uma visão de Sola Scriptura, e mantém uma postura de total abertura à filosofia grega, a qual Lutero repudia. Também podemos dizer que, enquanto este questiona o poder e o valor da Tradição eclesiástica, Santo Agostinho a enaltece.

Palavras-chave: Santo Agostinho, Lutero, Reforma
ABSTRACT: The present work has the propose to do an analysis of the extension of Saint Augustine's influence over Luther, with the objective of in some way to demark till which point Luther remains loyal to Saint Augustine in his doctrinaire visions defense. It's known that Luther was, before the Reformation, augustinian monk, and during and after the Reformation uses Saint Augustine to defend his doctrinaire visions: as, for example, the doctrine of justification only by faith (Sola Fide) and salvation only by grace (Sola Gratia). Actually, Saint Augustine becomes very important to the reformers, being cited many times in the reformer's writings. Such Reformation central doctrines concerning faith and grace are also broadly defended in augustinian writings. Nevertheless, as long as we can draw parallels between the augustinian doctrinaire visions and the lutheran ones, we can, equally, perceive contrasts. Saint Augustine, for example, does not defend a Sola Scriptura vision, and maintains a position of total openness to greek philosophy, which Luther criticizes. We can say also that, while Luther questions the power and the value of ecclesiastic tradition, Saint Augustine valorizes it.

KEYwORDS: Saint Augustine; Luther; Reformation

* Doutorando e mestre em filosofia pela Universidade Federal da Paraiba - UFPB. Professor de Filosofia da Faculdade Santíssima Trindade, Nazaré da Mata, PE. m@ilto: renanpmaia@gmail.com 


\section{INTRODUÇ̃̃o}

Presente trabalho tem como objetivo fazer uma análise da extensão da influência que Santo Agostinho lança sobre o reformador Martinho Lutero. Que houve influências agostinianas não só sobre Lutero, mas como sobre todo o movimento da Reforma Protestante é-nos patente não apenas pelo fato de Santo Agostinho ser citado diversas vezes pelos reformadores - por exemplo, no Livro de concórdia o Santo Doutor é mencionado trinta e seis vezes (The book of concord, 1959, p. 653), enquanto que nas Institutas da religião cristã, de Calvino, temos bem mais do que cem citações (vide: CALVIN, 2008, p. 1011-1014) - mas também pelas afinidades doutrinárias, sobretudo naquilo que diz respeito à doutrina da graça e da justificação pela fé. Todavia, isso não indica necessariamente que o movimento da Reforma seja um movimento essencialmente agostiniano, posto que entre Santo Agostinho e os reformadores há distanciamentos quanto a pontos doutrinários fundamentais - Tais como aqueles relativos à doutrina de Sola Scriptura, concernentes ao papel da filosofia na fundamentação das verdades da fé, sobre a conduta ascética etc., tal como abordaremos ao longo do presente escrito.

O presente trabalho tem como objetivo fazer uma análise da extensão da influência que Santo Agostinho lança sobre o reformador Martinho Lutero. Que houve influências agostinianas não só sobre Lutero, mas como sobre todo o movimento da Reforma Protestante é-nos patente não apenas pelo fato de Santo Agostinho ser citado diversas vezes pelos reformadores - por exemplo, no Livro de concórdia o Santo Doutor é mencionado trinta e seis vezes (The book of concord, 1959, p. 653), enquanto que nas Institutas da religião cristã, de Calvino, temos bem mais do que cem citações (vide: CALVIN, 2008, p. 1011-1014) - mas também pelas afinidades doutrinárias, sobretudo naquilo que diz respeito à doutrina da graça e da justificação pela fé. Todavia, isso não indica necessariamente que o movimento da Reforma seja um movimento essencialmente agostiniano, posto que entre Santo Agostinho e os reformadores há distanciamentos quanto a pontos doutrinários fundamentais - Tais como aqueles relativos à doutrina de Sola Scriptura, concernentes ao papel da filosofia na fundamentação das verdades da fé, sobre a conduta ascética etc., tal como abordaremos ao longo do presente escrito.

Assim sendo, o presente artigo visa, através da pergunta "Lutero, um agostiniano?" explorar os pontos de aproximação e distanciamento entre Agostinho e Lutero, tomando-o como representante primeiro e maior do movimento da Reforma, considerando ainda o fato de ter sido monge agostiniano anteriormente à Reforma. A primeira parte do artigo se destinará a analisar os pontos de aproximação, tais como: as concepções a respeito da graça, da justificação pela fé e da predestinação; e a segunda parte, por seu turno, se destinará a explorar os pontos de distanciamento, tais como: a importância atribuída por Santo Agostinho à filosofia, em geral tida como negativa por Lutero, a visão agostiniana de ascese, de celibato e de monasticismo, em geral criticada por Lutero como uma forma de legalismo, e as visões de ambos a respeito da relação entre a tradição e as autoridades eclesiásticas e as Escrituras.

\section{Aproximações entre Santo Agostinho e Lutero}

Quando surgiu o movimento da Reforma, naturalmente, as primeiras acusações foram as de colocarem a Reforma como um movimento inovador - em sentido negativo 
-, isto é, que trazia novas doutrinas, não condizentes com as verdades cristãs defendidas desde sempre pela tradição. A reação natural dos Reformadores foi a de demonstrar que tal acusação era na verdade um equívoco. E como fizeram isso? Demonstrando que os primeiros cristãos pensavam como eles. A Patrística, nesse sentido, se reveste de singular importância para os reformadores, pois demonstrar que as doutrinas da Reforma eram exatamente as mesmas das dos Padres da Igreja não era senão demonstrar que, se o poder eclesiástico era contrário à Reforma, isso se devia ao fato de que a Igreja se corrompeu, distanciando-se do que ensinavam os cristãos dos primeiros séculos. Tal nos fica patente pelo que lemos no prefácio das Institutas: escrito a Francis I, rei da França:

É uma calúnia nos colocar como sendo opostos aos padres (isto é, os escritores antigos de uma época mais pura), como se os padres fossem apoiadores da impiedade deles. Se a competição fosse para ser decidida por tal autoridade (para falar de modo moderado), a melhor parte da vitória seria nossa (CALVIN, ibidem, p. XXV).

Quando falamos em Patrística poucos nomes se equiparam em importância ao de Santo Agostinho, que inquestionavelmente definiu muitos dos rumos do Cristianismo em termos de teologia, de modo que a autoridade de Santo Agostinho acaba sendo invocada pelos reformadores no sentido de legitimar suas doutrinas. É o que acontece, por exemplo, com as doutrinas de Sola Gratia e de Sola Fide. Podemos constatar aproximações interessantes nestes pontos entre o Doctor Gratiae 1 e Lutero, ambos adotando posturas soteriológicas essencialmente monergistas, e mantendo uma postura pessimista quanto à possibilidade de o homem, por seu livre-arbítrio, conseguir salvar-se ou chegar-se a Deus. Detenhamo-nos um pouco nestes pontos de aproximação antes de falarmos dos pontos de distanciamento.

Ambos os pensadores abordam a questão do livre-arbítrio e de sua relação com a salvação, analisando em que medida o livre-arbítrio é eficaz com relação a esta. $\mathrm{Na}$ história da teologia e da filosofia cristã podemos mapear duas visões principais em torno do tema, uma sinergista, que afirma que o livre-arbítrio possui um papel fundamental no que diz respeito à salvação do homem; e uma monergista, que postula que o livre-arbítrio, por si só, é incapaz de conduzir o homem a Deus, sendo a salvação um produto da graça de Deus no homem.

Dentro destas visões o livre-arbítrio aparece como vinculado com outros elementos, como as obras que o homem pratica e o cumprimento da lei mosaica ou vetero-testamentária. Numa visão sinergista, a prática humana, suas obras e o cumprimento da lei vetero-testamentária ajudariam o homem, a partir da sua capacidade, a cumprir um papel importante em sua salvação, recebendo uma ajuda da graça divina. Numa visão, por outro lado, monergista, as obras e o esforço do livrearbítrio humano seriam completamente ineficazes para a salvação, sempre puxando o homem para o pecado. $\mathrm{Na}$ verdade, o homem, nesta perspectiva só conseguiria fazer verdadeiras boas obras por ele já ter sido em alguma medida salvo, isto é, já ter recebido a graça divina, sendo as obras resultado da graça, não proporcionadoras desta.

Como principal defensor de uma visão com ênfase no poder do livre-arbítrio com relação à salvação podemos citar, sem dúvidas, Pelágio, contemporâneo de Agostinho, e seus seguidores - os pelagianos - e, na época de Lutero, Erasmo de Rotterdam, que adota uma postura semi-pelagiana. ${ }^{2}$ Tanto Santo Agostinho quanto Lutero escreveram obras importantes afirmando o ponto básico do Cristianismo de que a salvação não parte do homem, mas de Deus, isto é, é pela graça, pelo sacrifício de Cristo, sendo o livre-arbítrio e as obras ineficazes no tocante à salvação, como diz São 
Paulo em Efésios 2,8-9. De Santo Agostinho temos, entre outras, as obras $A$ predestinação dos santos e o De libero arbitrio, e de Lutero temos, como sua obra mais importante sobre o tema, o De servo arbitrio.

O problema da liberdade humana é abordado por Santo Agostinho a partir de duas questões, uma delas é a de como a liberdade poderia ser conciliada com a noção de necessidade, que em grande medida caracterizaria a vontade divina, sua providência e presciência (o chamado "problema dos futuros contingentes"), já que a vontade divina e aquilo que Deus prevê em seu pensamento necessariamente se realiza, numa visão cristã, e nada acontece sem que Deus o queira ou o permita; a outra seria a relação da liberdade humana com a sua salvação. Ambas as questões, dentro do panorama filosófico e teológico cristão não são de fato dissociadas, uma vez que, se o homem age por necessidade e não por liberdade, fica a pergunta de como ele poderia ser responsabilizado pelos seus atos, posto que o pecado pressuporia uma escolha deliberada em relação a ele.

A questão da conciliação da noção de liberdade com a de presciência e providência divinas é solucionada pelo Santo Doutor ao longo do livro V da De civitate Dei. Mas, demonstrado haver liberdade humana ainda que exista a presciência e providência de Deus, fica ainda a questão de como tal liberdade se relaciona com a salvação. A liberdade seria suficiente para salvar ou condenar o homem? Agostinho, em sua obra De libero arbitrio, aborda a liberdade a partir de dois momentos: o homem antes da queda e do pecado original, e o homem depois da queda. O homem, no momento de sua criação, "não foi programado deterministicamente nem para o bem, nem para o mal" (COSTA, 2012, p. 46). Sua natureza era livre. Entretanto, após a queda, o homem perde sua condição de plena liberdade e passa a viver, em certa medida, em uma condição de necessitarismo, devido à sua natureza pecadora, e impossibilitado de libertar-se por si mesmo.

Isso não significa, contudo, que a alma ou o corpo do homem - que, em Santo Agostinho constituem uma unidade, não sendo o homem nem apenas corpo, nem apenas alma - sejam maus. Tudo o que é criado por Deus é bom, como nos exprime o primeiro capítulo do Gênesis. Todavia, no estado decaído do homem, a alma e o corpo passaram a um estado de desarmonia. Como diz Etienne Gilson,

o corpo do homem não é a prisão da sua alma, mas tornou-se tal por efeito do pecado original. (...) A natureza decaída é, pois, má na medida em que é viciada pelo pecado, mas é um bem enquanto natureza; exatamente, ela é esse mesmo bem em que o mal existe e sem o qual não poderia existir. (...) Transgressão à lei divina, o pecado original teve por consequência a rebelião do corpo contra a alma, de onde vêm a concupiscência e a ignorância. A alma foi criada por Deus para reger seu corpo, mas eis que é, ao contrário, regida por ele (GILSON, 1995, p. 153-154).

Tal condição decaída do primeiro homem é transmitida para os seus descendentes. Segundo Fraile, "para explicar a transmissão do pecado original lhe resulta muito mais fácil a teoria traducionista. Em sua carta a Optato de Milevi (...) lhe manifesta não ter todavia formada uma opinião própria” (FRAILE, 1986, p. 219). Em todo caso, há dois momentos e duas naturezas, uma criada em estado de inocência, e uma decaída. Como afirma o Agostinho:

Igualmente, quanto ao termo "natureza". Entendemos de um jeito, quando falamos em sentido próprio, isto é, a respeito da natureza específica, na qual o homem foi primeiramente criado no estado de inocência. De modo diferente, entendemos o termo "natureza" quando tratamos dessa natureza na qual, como 
consequência do castigo imposto ao primeiro homem, após sua condenação, nascemos mortais, ignorantes e escravos da carne, tal como disse o Apóstolo: "Como eles (os pagãos), nós (os judeus) também andávamos outrora nos desejos de nossa carne, satisfazendo as vontades da carne e os seus impulsos, e éramos por natureza como os demais, filhos da ira" (Ef 2,3). (AGOSTINHO, 1995, p. 212).

O homem, em sua natureza decaída, é incapaz de erguer-se por si mesmo ou de libertar-se do pecado. Segundo Agostinho,

se o homem fosse bom, agiria de outra forma. Agora, porém, porque está nesse estado, ele não é bom nem possui o poder de se tornar bom. Seja porque não vê em que estado deve se colocar, seja porque, embora o vendo, não tem a força de se alçar a esse estado melhor, no qual sabe que teria o dever de se pôr (AGOSTINHO, ibidem, p. 209).

A impossibilidade de o homem, por si mesmo, se erguer em direção a Deus o coloca como dependente da ação salvífica de Deus, do sacrifício de Cristo, que vem ao homem em sua forma humana e paga pelos pecados da humanidade, e de sua graça redentora. Pessanha afirma que para Agostinho "Deus é a bondade absoluta e o homem é o réprobo miserável condenado à danação eterna e só recuperável mediante a graça divina. Eis o cerne da antropologia agostiniana" (PESSANHA, 1984, p. 17). Gilson, sobre isso, também afirma: "No estado em que se encontra, a alma não pode se salvar por suas próprias forças. O homem pôde cair espontaneamente, isto é, por seu livrearbítrio, mas seu livre-arbítrio não lhe basta para tornar a se erguer" (GILSON, op. cit., p. 154).

Em seu debate com os pelagianos Agostinho combate a visão de que o homem, por seu livre-arbítrio, poderia direcionar-se ao bem ou ao mal. O livre-arbítrio humano é incapaz de conduzi-lo ao bem, a Deus e à salvação, mas apenas para o pecado ou para as coisas que estão no poder do homem, sendo o livre-arbítrio a única causa do mal. Todavia, o mal que o homem pratica não é colocado como sendo de responsabilidade de Deus, mas é devido à natureza decaída do homem, danificada pelo pecado original, cometido em liberdade por Adão e transmitido aos seus descendentes.

O sacrifício de Cristo seria o único antídoto que regeneraria a natureza humana, possibilitando ao homem entrar novamente em comunhão com Deus. Nesta religação (religare) do homem com Deus o homem não seria ativo, mas paciente, uma vez que dependeria da graça salvadora, e não das obras de seu livre-arbítrio, bastando para isso ter fé no sacrifício de Cristo que teria pago os pecados da humanidade. Todavia, em Agostinho a fé é já, ela mesma, obra da graça, sendo resultado. A graça, assim, é preveniente, não surge a partir de uma ação do homem em direção a Deus, mas de uma iniciativa de Deus em direção ao homem ou de uma eleição.

Agostinho, em sua obra A Predestinação dos santos (AGOSTINHO, 1999), cap. III, afirma que Deus é o autor da nossa fé, e falando sobre quando acreditava que a fé independia da graça, diz:

Não julgava que a fé fosse precedida pela graça de Deus, de sorte que por ele recebêssemos o que pedíssemos convenientemente, mas pensava que não podíamos ter fé, se não a precedesse o anúncio da verdade. Porém, o acolhimento à fé era iniciativa nossa, uma vez recebido o anúncio do Evangelho, e julgava ser merecimento nosso. Alguns opúsculos de minha lavra, escritos antes de ser ordenado Bispo, revelam com clareza este erro (III, 7)

Gilson, sobre isso, diz que sendo 
inciativa divina, a graça precede, portanto, em nós, qualquer esforço eficaz para nos reerguermos. Sem dúvida ela nasce da fé, mas a própria fé é uma graça. É por isso que a fé precede as obras, não no sentido de que as dispensa de consumá-las, mas porque as boas obras e seu mérito nascem da graça, e não inversamente (GILSON, op. cit., p. 155).

Desse modo, podemos perceber que Agostinho defende uma visão soteriológica estritamente monergista, isto é, onde Deus é o único responsável pela salvação do homem, posto que até mesmo a fé que o homem possui no sacrifício de Cristo e na redenção dos pecados é já, ela mesma, fruto da graça de Deus. $\mathrm{O}$ homem, assim, não contribuiria para sua própria salvação nem com suas obras, uma vez que, por sua liberdade, é incapaz de fazer o bem e alcançar a Deus, nem por sua capacidade de crer no sacrifício redentor, pois a fé já é um resultado da operação do Espírito Santo no homem.

O debate acerca do poder e do alcance do livre-arbítrio no tocante à salvação retorna no período do Renascimento através do debate entre Lutero e Erasmo de Rotterdam, este último defendendo, em sua obra Diatribe sobre o livre arbitrio uma visão humanista na qual o poder do livre-arbítrio do homem desempenharia um papel importante na salvação. Lutero, em resposta, publica a obra De servo arbitrio, título que é altamente reminiscente do De libero arbitrio de Santo Agostinho, e cujo conteúdo não o é menos, insistindo na completa insuficiência do livre-arbítrio do homem decaído no que diz respeito à salvação.

Erasmo define o livre-arbítrio como "a potência, através da qual o ser humano se pode inclinar ou afastar ao/do que leva à salvação eterna" (LUTERO, 1993, p. 14). A visão antropológica de Erasmo, segundo esta definição, é claramente semi-pelagiana, colocando na própria natureza humana um fator indispensável pelo qual o homem pode ser salvo ou condenado, contrariando as visões paulinas e agostinianas. De acordo com Beutel (2003, p. 15), "Erasmo opta pelo caminho do meio: no caminho para a salvação muitas coisas têm de ser atribuídas à graça divina e outras à vontade humana"”. A graça divina, na visão de Erasmo, entraria como uma espécie de ajuda ao livre-arbítrio que se direciona ao bem. A visão soteriológica de Erasmo seria, portanto, sinergista. Por outro lado, a incapacidade do homem em relação à salvação se torna o ponto central da teologia luterana, que centra-se no pressuposto de que o homem seria salvo apenas mediante a graça e justificado pela fé, sendo esta mesma obra da graça divina. Os lemas Sola Fide e Sola Gratia viriam, ao lado do Sola Scriptura, se tornar as bases do movimento da Reforma.

Ainda segundo Beutel,

Lutero faz a seguinte distinção: com respeito à sua relação com Deus, o arbítrio humano é completamente cativo. Por outro lado, com respeito ao seu relacionamento com coisas mundanas, a liberdade de escolha pertence aos homens (BEUTEL, idem).

Assim, não se trata de enxergar em Lutero um determinismo absoluto, como se defendesse que cada um dos nossos passos estivesse mecanicamente determinados. Nós, por nossa própria vontade, escolhemos as coisas inferiores em detrimento das superiores - o que, numa visão agostiniana, seria a origem do mal. Para que cheguemos às coisas superiores, precisamos da intervenção da graça.

Lutero faz a seguinte comparação:

se alguém te dissesse que é livre aquilo que, por seu próprio poder, só pode fazer algo numa direção, a saber, na má direção, ao passo que na outra direção, a saber na boa direção, pode fazer algo, mas não por seu próprio poder, e, sim, 
unicamente com auxilio de outro, poderias conter o riso, meu amigo? Pois assim demonstrarei facilmente que uma pedra ou um tronco tem livre-arbítrio, já que pode voltar-se tanto para cima quanto para baixo, mas por sua própria força só para baixo, e para cima só com o auxilio de outrem (LUTERO, 1993, p. 79).

De acordo com Lutero, o homem seria semelhante a uma pedra ou um tronco, que não poderia senão cair, não podendo escolher - e nem mesmo querer, uma vez que sua vontade é cativa - subir. Assim como a pedra só poderia ser erguida pela ação de alguém, o homem só poderia ser erguido em direção à salvação pela ação de Deus. Não haveria no homem qualquer faculdade que pudesse direcioná-lo para cima, mesmo no tocante à fé que seria já fruto do agir do Espírito Santo. Para fundamentar suas posições Lutero faz uso de diversas passagens bíblicas, tais como $\operatorname{Rm} 3,10$, Ef 2,8-9, $\mathrm{Hb} 10,38$, Jo 16,8 , Jo 6,44 .

Lutero permanece, assim, agostiniano no que diz respeito à doutrina da graça. De fato, no Livro de concórdia, o livro base onde estão escritas as doutrinas fundamentais do luteranismo, Santo Agostinho chega a ser citado diversas vezes, conforme já dito, algumas delas na Confissão de Augsburgo ${ }^{4}$, nos artigos sobre o livrearbítrio e o sobre a fé e as boas obras (The book of concord, op. cit., p. 39-40; 42-43).

Lutero, defendendo o Sola Gratia, cita Agostinho, dizendo:

Argumenta-se: o ser humano recebeu uma vontade livre pela qual ele merece ou deixa de merecer alguma coisa. A resposta a isso é: a vontade livre, constituída fora da graça, não possui, em absoluto, nenhuma aptidão para a justiça, mas encontra-se necessariamente em pecado. Por isso, o bem-aventurado Agostinho está certo em seu livro "Contra Juliano" quando ele diz a esse respeito: "É preferível uma vontade cativa a uma vontade livre." Porém, somente quando se tem a graça, a vontade torna-se propriamente livre, ao menos, com relação à salvação. A bem da verdade, ela é sempre livre num sentido natural; porém, apenas em relação àquilo que está em seu poder e lhe é subordinado, mas não no tocante às coisas que estão acima dela, uma vez que ela está presa em pecados e, nesse caso, não tem capacidade para escolher o que é bom aos olhos de Deus (LUTERO, 2003, p. 308-309).

As doutrinas de Sola Gratia e de Sola Fide, que seriam centrais na teologia da Reforma de Lutero, seriam assim apoiadas pela autoridade de Santo Agostinho. Também podemos mapear aproximações no tocante à doutrina da predestinação, a qual é defendida tanto por Santo Agostinho quanto por Lutero. A principal defesa da predestinação entre os escritos agostinianos estão na supracitada $A$ predestinação dos santos, onde a noção de predestinação aparece como uma decorrência lógica da própria noção de que apenas Deus é causa da salvação do homem. Em Lutero podemos mapear a mesma defesa da doutrina de que Deus predestina ou elege aqueles que haverão de crer e ser salvos, como quando, comentando os capítulos 9, 10 e 11 da epístola paulina aos romanos, diz:

Nos caps. 9, 10 e 11, [Paulo] ensina a eterna predeterminação de Deus. Desse conceito provém originalmente a distinção entre quem há de crer e quem não há, quem se pode livrar de pecados ou não. Com ele está de todo fora do nosso alcance e exclusivamente nas mãos de Deus que nos tornemos retos (LUTERO, ibidem, p. 139).

A doutrina da predestinação retorna com particular força na Reforma não apenas com Lutero, mas também como Calvino. Todavia, neste, temos a controversa noção de dupla predestinação - isto é, de que Deus predestina não apenas alguns para que creiam em Cristo e se salvem, mas também predestina alguns para serem condenados. Esta 
visão - a de predestinação para a condenação - contudo, não só não aparece em nenhum lugar de $A$ predestinação dos santos como também é rechaçada no Livro de concórdia (vide: Livro de concórdia, op. cit., p. 629).

\section{Pontos de distanciamento entre Santo Agostinho e Lutero}

Entre os pontos de distanciamento entre Santo Agostinho e Lutero podemos elencar pelo menos três: as visões a respeito da relação entre filosofia e teologia ou, em outros termos, sobre a possibilidade de se fundamentar racionalmente as verdades da fé; as visões a respeito do monasticismo, do celibato e da conduta ascética e, enfim, as visões a respeito da autoridade eclesiástica e sua relação com as Sagradas Escrituras. Trataremos brevemente sobre cada um destes pontos.

Sobre o primeiro ponto, convém dizer que a crítica de Lutero não se limita a Erasmo e ao seu semi-pelagianismo, mas a todo o aristotelismo em algum grau dominante na teologia católica da época, a qual Lutero coloca como também sendo essencialmente contrária à doutrina da graça. No Debate sobre a teologia escolástica, Lutero já havia atacado a visão de que a vontade humana, em conformidade com a razão, poderia escolher entre o bem e o mal, particularmente a de Duns Scotus e Gabriel Biel. Verdade é que ética aristotélica trazia esta visão com sua noção de agir segundo a "reta razão". Nesta mesma obra Lutero chega a afirmar que "quase toda a Ética de Aristóteles é a pior inimiga da graça", sendo "um erro dizer que a concepção de felicidade de Aristóteles não contraria a doutrina católica” (LUTERO, 1987, p. 17), ou que sem Aristóteles e sem ser um lógico ninguém poderia se tornar teólogo.

As críticas a Aristóteles redundam, como é de se esperar, numa forte crítica a Santo Tomás, como vemos em Do cativeiro babilônico da igreja (LUTERO, 2006, p. 34-35). Todavia, do fato de os escolásticos terem bebido de Aristóteles não decorre que eles aceitavam absolutamente tudo de Aristóteles, ou que eram mais aristotélicos do que cristãos. Santo Tomás, por exemplo, reafirma, no Tratado sobre a graça, parte da Summa theologica, que é a graça de Deus quem realiza a salvação do homem, operando nele o conhecimento de Deus (vide: AQUINAS, 1952, p. 338-378) ${ }^{5}$ e as infundindo nele as virtudes teologais, as quais são inacessíveis ao homem apenas com as potências de sua própria natureza, como vemos na Summa Theologica, Q. 62, pt. I da pt. II (AQUINAS, ibidem, p. 60). Santo Tomás postula, nesse sentido, essencialmente o mesmo que Santo Agostinho e as resoluções conciliares em torno do pelagianismo e do semi-pelagianismo - Já falamos que em Santo Agostinho mesmo a fé, virtude teologal, é obra da graça, como coloca na $A$ predestinação dos santos; quanto às resoluções conciliares, temos condenações formais do pelagianismo e do semi-pelagianismo no Concílios de Éfeso (DENZINGER, 2006, p. 102-103) e no Sínodo de Orange (DENZINGER, ibidem, p. 139-146).

As críticas de Lutero à razão e às influências de filosofia direcionadas a Santo Tomás, Gabriel Biel e Duns Scotus, contudo, podem muito bem ser entendidas como um distanciamento claro em relação a Santo Agostinho, afinal se é verdade que os escolásticos mencionados se deixaram influenciar por Aristóteles, é igualmente verdade que Santo Agostinho foi, em não menor grau, influenciado por Platão e Plotino, como bem se sabe. Em Santo Agostinho fé e razão não são contrapostas, mas complementares. Segundo Fraile, para Agostinho

a razão e a fé são coisas distintas, mas no homem cristão não funcionam isoladamente, senão em íntima e fecunda compenetração. (...) A insuficiência da filosofia encontra seu complemento na plenitude da verdade descoberta pela fé. 
Desde que sua alma se sente inundada pelos resplendores da fé, já não haverá para ele um funcionamento autônomo da pura razão. Sua alma descansa na possessão da verdade que lhe ministra a fé, e por sua vez a fé vivida penetra, sem a anular, até o mais intime de sua razão (FRAILE, op. cit., p. 197).

Daí a expressão agostiniana "Intellige ut credas. Crede ut intelligas" ("Entenda para que creias. Creia para que entendas"). Para Lutero, por outro lado, razão e fé são coisas separadas, de certo modo contrapostas. Embora a razão seja capaz de nos fornecer muitas verdades, ela jamais terá a palavra final no que diz respeito às verdades mais elevadas, que só podem ser acessíveis mediante a revelação divina e as Escrituras. As verdades últimas são inacessíveis à razão. Lutero, a este respeito, diz:

A sua absurdidade é uma das principais causas para que as palavras de Moisés e de Paulo não sejam compreendidas em sua simplicidade. Mas contra que artigo de fé peca esta absurdidade? Ou quem se ofende com ela? A razão humana se ofende, razão que, embora cega, surda, estulta, ímpia e sacrílega no tocante a todas as palavras e obras de Deus, por meus opositores é chamada para ser juíza das palavras e das obras de Deus (LUTERO, 1993, p. 125)

Ainda sobre a razão, ele afirma:

A filosofia, ou ciência humana, define o homem como um ser com razão, sentimento e corpo. Mas é preciso saber que esta definição diz respeito ao homem apenas enquanto mortal e ao espaço de sua vida. E certamente é verdade que a razão é o que há de mais importante e mais elevado, sendo, em comparação com as outras coisas desta vida, a melhor, algo divino. [...] Por isso, convém que ela seja chamada de diferença essencial pela qual o homem se distingue dos animais e das outras coisas. A Escritura Sagrada também a constitui senhora sobre a terra, as aves, os peixes, o gado, ao dizer: 'Dominai' (Gn 1.28). Contudo, se se comparar a filosofia ou a própria razão com a teologia, ficará evidente que não sabemos quase nada sobre o homem. A partir da plenitude de sua sabedoria, a teologia define o homem de maneira total e perfeita. A saber, que o homem é criatura de Deus constituída de corpo e alma viva, feita no princípio à semelhança de Deus, sem pecado, a fim de procriar e dominar sobre as coisas, sem nunca morrer. Mas que, após a queda de Adão, a criatura ficou sujeita ao poder do diabo, ao pecado e à morte, um mal duplo, insuperável para as suas forças e eterno. $\mathrm{E}$ disso não pode ser libertada e receber a vida eterna a não ser pelo Filho de Deus, Jesus Cristo (se nele crê). (LUTERO, 1992b, p. 194).

O fundamento do Sola Scriptura e do conhecimento revelado defendido por Lutero reside, então, no fato de que a razão não só é completamente incapaz de chegar ao conhecimento da Verdade, mas é "ímpia e sacrílega", levando sempre ao erro. Assim, a filosofia, seja aristotélica ou neoplatônica, é colocada em segundo plano na visão luterana. ${ }^{6}$ Para Agostinho, a razão, bem como a filosofia, poderiam fornecer bons fundamentos na defesa da fé, como o demonstra largamente em suas obras. E, de fato, Santo Agostinho chega a falar nas Confissões que encontrou na Bíblia muitas verdades que leu outrora nos escritos dos platônicos, porém na Bíblia realçadas com a graça (AGOSTINHO, 1984, p. 124).

Quanto ao segundo ponto, a saber, aquele em relação ao monasticismo, ao celibato e à conduta ascética, podemos perceber, por um lado, uma legitimação por parte de Santo Agostinho, ele mesmo tendo vivido de forma celibatária, e por outro, uma forte crítica por parte de Lutero. Cabe lembrar que Lutero já havia sido monge, quebrando, posteriormente, seus votos e casando com Katharina von Bora. Sua mudança em torno da questão do monasticismo, do celibato e da conduta ascética são sintetizadas na pt. III, art. XI e XIV dos seus Artigos de Esmalcalde, sobre o casamento 
dos sacerdotes e dos votos monásticos, respectivamente:

Os papistas não têm nem autoridade e nem direito de proibir o casamento e de atar o estado divino dos sacerdotes ao celibato perpétuo. Ao contrário, eles agem como anticristãos, tiranos e canalhas, e dão ocasião a toda sorte de pecados sem conta, terríveis e abomináveis, nos quais estão ainda envolvidos. [...] Tão pouco quanto o poder que nos foi dado para fazer de um homem uma mulher ou uma mulher de um homem ou de abolir as distinções de sexo é o poder que temos de separar tais criaturas ou de proibi-los de viver juntos em honesto matrimônio (The book of concord, op. cit., p. 314).

E mais adiante:

Quem quer que faça votos de vida monástica acredita que está entrando num modo de vida que é melhor que aquele modo de vida cristão ordinário e propõe por meio desta obra ajudar não apenas a si mesmo, mas a outros a entrarem no paraíso. Isto é negar a Cristo, etc. E na autoridade do Santo Tomás deles tais pessoas se gabam de que um voto monástico é igual ao batismo. Isto é blasfêmia (The book of concord, ibidem, p. 315-316). ${ }^{7}$

Como se nota, Lutero vincula o voto monástico a uma espécie de legalismo, como se o monge pretendesse se justificar, por seus próprios méritos, ao entrar na vida monacal. Santo Agostinho, por seu turno, parece não ver contradição entre as condutas ascéticas do celibato e do monasticismo com a doutrina da graça, a qual, sem dúvidas, ele se coloca como um dos mais importantes defensores. Primeiramente, porque ele mesmo viveu por um tempo de forma monacal, estabelecendo diferentes monastérios, sendo o primeiro em Tagaste e o segundo em Hipona, conforme nos diz Fraile (op. cit., p. 193-194) e, conforme nos diz Pessanha (op. cit., p. 10), Santo Agostinho pretendia viver o resto de sua vida recolhido no primeiro monastério que fundou, sendo, meio que a contragosto, afastado deste caminho, assumindo a função episcopal em Hipona. Mas mesmo enquanto já bispo de Hipona, estabelece um centro monástico em sua residência (FRAILE, op. cit., p. 194). Quanto à questão da vida monacal, Santo Agostinho parece não demonstrar nenhuma mudança de opinião, como Lutero demonstra. Muito pelo contrário, em diversos momentos de seus escritos o Santo Doutor parece enaltecer a conduta ascética, típica da vida monacal, como sendo o ideal de conduta cristã.

Podemos ver isso de modo patente nas Confissões, livro X, cap. 30-39 (AGOSTINHO, 1984, p. 191-203), onde o Doctor Gratiae delineia como ideal de vida cristã o completo e total desprendimento em relação aos prazeres da mesa, dos perfumes, da música do olhar, em relação à curiosidade, ao orgulho, ao louvor, à vanglória e ao amor-próprio. Podemos constatar o viés marcadamente ascético de Agostinho ao ver como ele coloca como negativo o apego a coisas que hoje vemos como completamente boas, neutras ou, no mínimo, não-ofensivas, tais como o gosto pela música. Santo Agostinho prega, com suas palavras nas Confissões, o completo desapego de tudo o que seja proveniente dos sentidos. Também podemos ver esse contínuo buscar pelo total e completo desapego às coisas provenientes dos sentidos em sua obra Sobre a potencialidade da alma, onde o bispo de Hipona traça sete graus pelos quais a alma passa em seu completo desapego a todas as coisas sensíveis e em sua ascensão até a contemplação de Deus (vide: AGOSTINHO, 2013, p. 159-166).

Quanto ao celibato, por seu turno, o Bispo de Hipona enaltece-o em diferentes momentos, como vemos, por exemplo, nos Solilóquios, ao falar sobre a possibilidade de ter uma esposa:

Por mais que queiras pintá-la e cumulá-la de todas essas vantagens, decidi que 
nada devo evitar tanto como a coabitação conjugal. Acho que não existe nada que possa abater o ânimo viril mais que as carícias femininas e o contato dos corpos, sem o qual não se pode ter esposa. Por isso, se é obrigação do sábio dedicar-se aos filhos (o que ainda não constatei), e só por isso é que ele coabita, isso pareceme que é mais de se admirar, mas de modo algum imitar; pois há maior perigo em tentar fazer que felicidade em ser capaz de fazê-lo. Pelo que acho que minha decisão de não desejar nem procurar esposa nem casar-me foi uma decisão suficiente, justa e útil, pela liberdade de minha alma (AGOSTINHO, 1998, p. 37$38){ }^{8}$

Vemos assim de certo modo o enaltecimento de uma conduta ascética e da vida monacal em Agostinho, de modo que este não via qualquer contrariedade entre o rigor da vida monástica, ascética e celibatária e a doutrina de que a salvação vem da graça, e não das obras e do cumprimento da lei, ao contrário do que podemos ver em Lutero. O'Donnell chama a atenção para o modo como Agostinho desde sua conversão opta pelo caminho da ascese e do celibato:

Nada do Cristianismo o obrigava a abandonar a atividade sexual para ser batizado, mas Agostinho buscou algo mais elevado: a vida do filósofo cristão, separado do caminho ordinário do cristão e superando os mais ascéticos e etéreos filósofos não-cristãos (O’DONNELL, 2006, p. 18)

Poderíamos falar, por fim, como estando entre as diferenças realmente fundamentais, aquela referente à relação entre a Igreja e as Sagradas Escrituras. Do princípio luterano de Sola Scriptura decorre com necessidade a conclusão de que a Igreja deve se fundar e se limitar àquilo que aparece na Bíblia. Podemos ver essa concepção de modo claro em Lutero já na Dieta de Worms, quando se recusa a se retratar por suas doutrinas, a menos que fosse convencido de que estava errado pela autoridade bíblica, colocando a autoridade papal e dos concílios abaixo das Sagradas Escrituras, dizendo:

a não ser que seja convencido por testemunho das Escrituras ou por argumento evidente da razão (pois não acredito nem no papa nem nos concílios exclusivamente, visto que é certo que os mesmos erraram muitas vezes e se contradisseram a si mesmos) - estou vencido pelas Escrituras por mim apresentadas e minha consciência está presa nas palavras de Deus - não posso nem quero retratar-me de nada, porque agir contra a consciência não é prudente nem íntegro. Que Deus me ajude. Amém (LUTERO, 2012, p. 1015).

Em Santo Agostinho, por sua vez, não temos qualquer base para a ideia de um Sola Scriptura. Primeiro porque, como já vimos, o Santo Doutor não deixa de admitir como válidas formas de conhecimento extra-bíblicas, como é o caso da filosofia grega. Em segundo lugar, não só não existe de modo claro a ideia de que a autoridade da Igreja está abaixo das Escrituras Sagradas, como podemos ver em certos momentos, inclusive, a ideia contrária, isto é, a ideia de que a Bíblia extrai sua autoridade do magistério da Igreja. É caso quando diz: "Eu não creria no Evangelho, se a isto não me levasse a autoridade da Igreja católica" (Catecismo da Igreja Católica, 1999, p. 43)9. Rist comenta que para

Agostinho, a mente humana deveria ser usada para o discernimento de autoridades; é inadequado e irracional identificar certas verdades teológicas importantes, e provavelmente também éticas e estéticas, sem essas autoridades. Agostinho afirmou que não teria acreditado nos Evangelhos sem a autoridade da Igreja Católica (C. ep. Fund. 5.6). Mas ele também está ciente de que o discernimento humano é empobrecido e ele culpa a queda por esse 
empobrecimento. Como, então, ele sabe que ele discerniu suas autoridades corretamente? Claro, ele não sabe, mas ele afirma verdadeira crença ou fé. $\mathrm{Na}$ medida em que seus discernimentos são corretos, essa correção foi alcançada através da graça e da ajuda de Deus - que muitas vezes pode ser identificada retrospectivamente. Deus trabalha na história para mostrar quais indivíduos e quais instituições merecem a crença teológica, e no indivíduo para permitir que ele veja o que ele normalmente não enxerga (RIST, 2006, p. 32).

A frase em questão ("Eu não creria no Evangelho...”) nos deixa clara exatamente a ideia oposta a de Lutero. Enquanto que para este a Igreja estava em certo sentido abaixo das Escrituras, para Agostinho, pelo contrário, as Escrituras estavam ao lado da Igreja, já que seria um fruto da tradição eclesiástica, e posto que Deus se revela não apenas nas Escrituras, mas também na autoridade da Igreja. Podemos entender isto no sentido de que o cânon bíblico - e, portanto, a própria noção de Bíblia - é definido pela tradição e pela autoridade eclesiásticas, e não inverso, e também de que a interpretação bíblica cabe ao magistério eclesiástico.

Além disso, temos que, na época do Doctor Gratiae, ninguém questionava a autoridade do clero senão os considerados hereges. E, cabe dizer, Santo Agostinho polemizou com todas as heresias de seu tempo, sendo a parte mais substancial de seus escritos contra as heresias de sua época: como contra o maniqueísmo, o arianismo, o donatismo etc (vide: FRAILE, op. cit., p. 193-195). Em outras palavras, na disputa entre a tradição e as formas de Cristianismo consideradas heréticas, em todos os momentos após sua conversão Agostinho optou por ficar ao lado da tradição. O mesmo não se pode dizer de Lutero. Não só por ele mesmo questionar a tradição e a autoridade eclesiástica, mas também por assumir as perspectivas daqueles que questionaram, como no caso de Jan Hus (LUTERO, 1987, p. 350), condenado como herege pelo Concílio de Constança, e de Pico dela Mirandola (LUTERO, ibidem, p. 120), que também caiu em controvérsias com a ortodoxia.

Conclusão.

A partir do exposto, podemos concluir que há tanto pontos de aproximação quanto pontos de distanciamento entre Santo Agostinho e Lutero, todos estes se dando em aspectos igualmente fundamentais dos pensamentos de ambos os pensadores. Assim, respondendo à pergunta proposta no título do presente artigo, não se pode de fato falar de Lutero como um agostiniano, sem que isso cause confusões e atropelos em doutrinas fundamentais de ambos os pensadores. De igual modo, não se pode dizer que exista uma total ruptura por parte de Lutero em relação a Santo Agostinho. De fato, Lutero, nas polêmicas contra as indulgências e acerca do papel do livre-arbítrio com Erasmo, se pretende, em grande medida, resgatador de visões agostinianas em tese esquecidas pela Igreja de seu tempo, tais como aquelas acerca da graça, da justificação pela fé e da predestinação. Importa dizer, contudo, que estas doutrinas não eram de fato esquecidas ou ignoradas pela Igreja do séc. XVI. Se é verdade que a Igreja da época de Lutero era a Igreja tomista, como diz em Do cativeiro babilônico da igreja (LUTERO, 2006, p. 34), é interessante notar que, como colocamos antes, Santo Tomás igualmente faz ampla defesa da doutrina da graça em sua Summa theologica. E é com certa segurança que podemos afirmar que a Summa theologica era no tempo de Lutero uma obra mais referencial de doutrina católica do que qualquer obra de Erasmo.

Por fim, poderíamos concluir que a negativa de que Lutero era um agostiniano é ainda mais verdadeira se, no lugar de Lutero, colocarmos outros reformadores, uma vez que tais pensadores e teólogos levam as visões doutrinárias de Lutero a outros níveis de desenvolvimento e a novas consequências. É o caso de Calvino com a TULIP ${ }^{10}$, por exemplo, com visões como a de expiação limitada, não previstas nem em Lutero e, 
igualmente, também não em Santo Agostinho. O mesmo poderíamos falar em relação às concepções em torno de Maria, que é enaltecida não só por Agostinho ${ }^{11}$, mas também por Lutero, como vemos em seu Magnificat (LUTERO, 2015), mas que tende a ter sua importância diminuída nos protestantes pós-Lutero, consolidando-se a importância atribuída a Maria um dos aspectos distintivos fundamentais entre o catolicismo e o protestantismo.

\section{REFERÊNCIAS}

AGOSTINHO, S. A predestinação dos santos. In: AGOSTINHO, S. A graça (II). Tradução de Augustinho Belmonte. São Paulo: Paulus, 1999.

AGOSTINHO, S. O livre-arbitrio. Tradução, organização e notas: Nair de Assis Oliveira. São Paulo: Paulus, 1995.

AGOSTINHO, S. Os Pensadores. $3^{\text {a }}$ ed. São Paulo: Abril Cultural, 1984.

AgOSTINHO, S. Sobre a potencialidade da alma. Tradução de Aloysio Jansen de Faria. Petrópolis, RJ: Vozes, 2013.

AGOSTINHO, S. Solilóquios e a vida feliz. São Paulo: Paulus, 1998.

AUGUSTINE, S. The confessions, the city of God, on christian doctrine. Encyclopaedia Britannica. Chicago: William Benton, 1952.

AQUINAS, T. The summa theologica. Translated by Fathers of the English Dominican Province. Encyclopaedia Britannica. Chicago, William Benton, 1952.

BEUTEL, A. Luther's life. In: McKIN, Donald (editor). The Cambridge Companion to Martin Luther. Cambdrige: Cambridge University Press, 2003.

CALVIN, J. Institutes of the christian religion. Translated by Henry Beveridge. Massachusetts: Hendrickson Publishers, 2008.

Catecismo da Igreja Católica. São Paulo: Edições Loyola, 1999.

COSTA, M. R. N. 10 lições sobre Santo Agostinho. $2^{\mathrm{a}}$ ed. Petrópolis, RJ: Vozes, 2012.

DENZINGER, H. Compêndio dos símbolos, definições e declarações de fé e moral da Igreja Católica. Tradução de José Marino Luz e Johan Konings. São Paulo: Paulinas e Loyola, 2006.

FRAILE, G. Historia de la filosofia II: El Cristianismo y la filosofia patrística. Primera escolástica. Madrid: Biblioteca de Autores Cristianos, 1986.

GILSON, E. A filosofia na Idade Média. Tradução de Eduardo Brandão. São Paulo: Martins Fontes, 1995.

GRIGNION, S. L. M. Tratado da verdadeira devoção à santíssima virgem. $46^{\mathrm{a}}$ ed. Petrópolis, RJ: Vozes, 2015.

HÄGGLUND, B. História da teologia. Tradução de Mário L. Rehfeldt e Gládis Knak Rehfeldt. Porto Alegre, RS: Editora Concórdia, 1981.

AFONSO, S. Glórias de Maria. $3^{\text {a }}$ ed. Aparecida, SP: Editora Santuário, 1989.

LUTERO, M. Bíblia Sagrada com reflexões de Lutero. São Paulo: Sociedade Bíblica do Brasil, 2012.

LUTERO, M. Do cativeiro babilônico da igreja. Tradução de Martin N. Dreher. São Paulo: Martin Claret, 2006.

LUTERO, M. Magnificat: o louvor de Maria. Aparecida, SP: Editora Santuário; São Leopoldo: Editora Sinodal, 2015.

LUTERO, M. Nascido escravo. $1^{\text {a }}$ ed. São José dos Campos, SP: Editora Fiel, 1992a.

LUTERO, M. Obras selecionadas vol. 1. São Leopoldo e Porto Alegre: Editoras Sinodal e Concórdia, 1987.

LUTERO, M. Obras selecionadas vol. 3. São Leopoldo e Porto Alegre: Editoras Sinodal e Concórdia, $1992 b$.

LUTERO, M. Obras selecionadas vol. 4. São Leopoldo e Porto Alegre: Editoras Sinodal e Concórdia, 1993.

LUTERO, M. Obras selecionadas vol. 8. São Leopoldo e Porto Alegre: Editoras Sinodal e 
Concórdia, 2003.

O'DONNELL, J. J. Augustine: his time and lives. In: STUMP, E., KRETZMANN, N. The Cambridge companion to Augustine. Cambridge: Cambridge University Press, 2006.

PESSANHA, J. A. M. Santo Agostinho: Vida e Obra. In: AGOSTINHO, S. Os Pensadores. $3^{\text {a }}$ ed. São Paulo: Abril Cultural, 1984.

206 RIST, J. Faith and reason. In: STUMP, E., KRETZMANN, N. The Cambridge companion to Augustine. Cambridge: Cambridge University Press, 2006.

RIST, J. The book of concord: The confessions of the evangelical lutheran church. Translated and edited by Theodore G. Tappert. Philadelphia: Fortress Press, 1959.

\section{Notas}

1 Doutor da Graça, título atribuído a Santo Agostinho.

2 Ou sinergista.

3 Esta é a posição sinergista do semi-pelagianismo.

4 A Confissão de Augsburgo, que resume os principais artigos da fé luterana, não foi escrita por Lutero, mas por seu amigo Felipe Melancton, sendo Lutero, todavia, consultado.

5 Q. 109-114, pt I da pt. II.

6 Embora Lutero, paradoxalmente, se reconheça como admirador de Santo Agostinho, o qual não deixa de valorizar a filosofia, e de místicos como Johannes Tauler (LUTERO, 1987, p. 98), de influências claramente neoplatônicas. Há também estudiosos que postulam uma influência de Ockham sobre Lutero (HÄGGLUND, 1981, p. 184).

7 Obviamente, Lutero está aí a ignorar passagens bíblicas em que o celibato é colocado como algo positivo, como Mt 19,12, Lc 9,23 e 1Co 7,9-10.

8 Apesar de sua opção pessoal pelo celibato, Santo Agostinho parece variar quanto à abstinência, demonstrando visões mais abertas em relação a sexualidade com o passar do tempo, conforme nos aponta Costa (op. cit., p. 73-80). Todavia, as concessões que Agostinho faz à sexualidade não deixam de se restringir àqueles que seguem a vocação do matrimônio.

9 "Ego vero Evangelio non crederem, nisi me catholicae Ecclesiae commoveret auctoritas" (Contra epistolam manichaei quam vocant fundamenti, 5,6: PL 42,176).

10 Os cinco pontos doutrinários fundamentais do calvinismo.

11 São Luís Maria Grignion de Montfort em seu Tratado da verdadeira devoção à santíssima virgem traz visões e dizeres significativos de Santo Agostinho sobre este tema (vide: GRIGNION, 2015, p. 36, 51, 81, 215, 225). O mesmo faz Santo Agonso de Ligório em seu Glórias de Maria (vide: AFONSO, 1989, p. 24, 27...) 